\title{
COMPARISON OF TWO PLANNING TECHNIQUES (FiF/IMRT) FOR POSTOPERATIVE RADIATION THERAPY OF PROSTATE CANCER
}

\author{
NEVENA OBAJDIN ${ }^{1}$, ĐENI SMILOVIĆ RADOJČIĆ ${ }^{1,2}$, \\ DAG ZAHIROVIĆ ${ }^{3}$, MANDA ŠVABIĆ KOLACIO ${ }^{1}$, DAVID RAJLIĆ ${ }^{1}$, \\ INGRID BELAC LOVASIĆ ${ }^{3,4}$ and SLAVEN JURKOVIĆ ${ }^{1,2}$ \\ ${ }^{1}$ Medical Physics Department, University Hospital Rijeka, Rijeka, Croatia; \\ ${ }^{2}$ Department of Medical Physics and Biophysics, Faculty of Medicine, \\ University of Rijeka, Rijeka, Croatia; \\ ${ }^{3}$ Clinic for Radiotherapy and Oncology, University Hospital Rijeka, Rijeka, Croatia; \\ ${ }^{4}$ Department of Oncology and Radiotherapy, Faculty of Medicine, University of Rijeka, Rijeka, Croatia
}

\section{Summary}

Introduction: Within the past two decades, we made significant progress in radiation therapy for prostate cancer. At UH Rijeka IMRT became the technique of choice for radiation therapy following radical prostatectomy since 2016. Previously, an advanced 3-DCRT technique using the field-in-field (FiF) method was used for dose distribution optimization around target volumes and organs-at-risk. This research has been performed to investigate the influence of planning technique choice (FiF or IMRT) on coverage of target volumes with prescribed dose and organs-at-risk sparing.

Materials and methods: Comparison of dose distributions calculated using FiF and IMRT techniques was performed retrospectively for ten patients who underwent postoperative radiotherapy. The prescribed dose for all patients was delivered using IMRT, and for this research, we also calculated dose distributions using the FiF technique. For FiF and IMRT techniques, we used linear accelerator photon beams. To determine the influence of planning technique on dose distribution parameters related to target volumes (GTV, CTV, PTV ${ }_{1}, \mathrm{PTV}_{2}$ ) were analyzed. For organs-at-risk sparing evaluation (rectum, bladder, femoral heads), we used dose-volume constraints.

Results and discussion: The analysis of parameters related to target volumes has shown that most of them had no statistically significant difference (V100\%(GTV), V100\%(CTV), V95\%( $\left.\left.\mathrm{PTV}_{2}\right), \mathrm{V} 95 \%\left(\mathrm{PTV}_{1}\right)\right)$. For both planning techniques, internationally set dose constraints were achieved. Statistically, we found a significant difference for $\mathrm{V} 100 \%(\mathrm{PTV}), \mathrm{p}=0,000534$, and V100\% $\left(\mathrm{PTV}_{1}\right), \mathrm{p}=0,042944$ in favor of IMRT. A statistically significant difference $(\mathrm{p}=0,045966)$ was found for the volume of the rectum, which receives $40 \mathrm{~Gy}$, and for the volume of femoral heads, which receives $30 \mathrm{~Gy}$ ( $\mathrm{p}=0,000385$ ), where the sparing is better for IMRT. For dose-volume constraints related to the bladder, no statistically significant differences were found.

Conclusion: Results of this research show a statistically significant difference for $\mathrm{V} 100 \%$ target volume coverage for $\mathrm{PTV}_{1}$ and $\mathrm{PTV}_{2}$, with better dose coverage accomplished by IMRT. Concerning organs-at-risk sparing, a statistically significant difference in favor of IMRT was found for rectum volume, which receives 40Gy. Expectedly, IMRT was superior to the $\mathrm{FiF}$ technique. However, differences between the two planning techniques were relatively small, which points to the fact that the FiF technique is viable as a technique of choice.

KEYWORDS: intensity-modulated radiation therapy, field-in-field technique, postoperative prostate cancer radiotherapy, radiation dosimetry.

Corresponding author: Nevena Obajdin, Medical Physics Department, University Hospital Rijeka, Krešimirova 42, 51000 Rijeka, Croatia.e-mail: nobajdin@yahoo.com 


\section{INTRODUCTION}

Globally, more than $50 \%$ of oncological patients require radiotherapy treatment (1). In Croatia, prostate cancer makes up $17.4 \%$ of all diagnosed cancer cases in the male population (2). In cases with high-risk and very-high-risk prostate cancer, radical prostatectomy is followed by radiation therapy (3). Recently, radiotherapy of prostate cancer in salvage radiotherapy tends to be a standard approach for cases of biochemical recurrence based on postoperative prostate-specific antigen (PSA) levels (4). Studies have shown that local recurrence of the disease happened less often in patients who underwent radiotherapy following radical prostatectomy $(5,6)$. During treatment planning, the main challenge is the compromise between higher target volume coverage and better organs-at-risk sparing. In the past two decades, large progress has been made in new radiation technologies used to treat prostate cancers, with further development of medical linear accelerator, calculation algorithms built-in treatment planning system and, consequently, radiation oncology treatment planning techniques (7).

Intensity-modulated radiation therapy (IMRT) is one of the advanced treatment planning techniques used in radiation therapy treatment planning following radical prostatectomy (3). It has been the choice technique at University Hospital Rijeka since 2016 when the system for dose distribution calculation and optimization based on the Monte Carlo algorithm had been clinically implemented. Formerly, the advanced 3D conformal radiotherapy field in field (FiF) technique was used for dose distribution optimization around target volumes and organs-at-risk. Generally, the concept of IMRT is that the dose distributions are inversely determined, meaning that the desired dose distribution optimization goals concerning target volume coverage and organs-at-risk sparing must be specified prior to calculation. The prescribed dose is to be delivered to the respective volumes with strict precision. Forward FiF technique is a simplified form of IMRT with a limited number of segments per field, whose shape and a physicist optimizes weight to deliver the prescribed dose to the target and obtain, at least, required organs-at-risk sparing. Organs-at-risk sparing requires the fulfillment of dose-volume constraints to avoid acute and long-term side ef- fects. For radiation oncology treatment of prostate cancer, it was shown that patients who developed acute symptoms were more likely to develop late toxicities for both rectum and bladder (8). Achieving as low as possible doses to organs-at-risk while maintaining sufficiently high target volume coverage helps to reduce acute and long-term toxicity.

This research aimed to investigate the influence of planning technique (FiF or IMRT) on prescribed dose coverage of target volumes and sparing of organs-at-risk.

\section{MATERIALS AND METHODS}

\section{Study design}

Retrospective analysis of dose distributions for ten patients who underwent postoperative radiotherapy at the Clinic for Radiotherapy and Oncology of UH Rijeka was performed for this research.

Pre-treatment procedures were undertaken in preparation for radiation oncology treatment in accordance with the in-house protocol. Siemens Somatom Open CT simulator (Siemens Healthineers, Erlangen, Germany) was used to acquire the imaging data. Computerized tomography (CT) was performed for all patients, who were scanned in the supine position with $3 \mathrm{~mm}$ slice thickness. Bottom and top scan borders were set at the proximal part of the femur and the third lumbar vertebra.

Prior to the CT simulation, patients were instructed to follow the full bladder and empty rectum preparation protocol (9). Radiation oncologist delineated target volumes using Elekta Monaco Sim (ver 5.11.02, Elekta, Stockholm, Sweden) workstation. The prostate bed was designated as gross target volume (GTV) and lymph nodes as the clinical target volume (CTV). Planning target volumes (PTVs) were created in accordance with international guidelines (10): $\mathrm{PTV}_{1}$, created by adding an $0.7 \mathrm{~cm}$ margin around CTV and a $1.0 \mathrm{~cm}$ margin around GTV, and $\mathrm{PTV}_{2^{\prime}}$ created by adding a $1.0 \mathrm{~cm}$ margin around the prostate bed (GTV). Relevant organs-at-risk were also delineated. Bladder volume was delineated as the whole bladder. Rectum was delineated as the region from the sigmoid colon superiorly to the anal canal inferiorly, including rectal wall and cavity. The entire 
volume of both organs was delineated, including the filling. The Left and right femoral heads were also delineated.

The prescribed dose to be delivered to $\mathrm{PTV}_{1}$ was 46Gy in 23 fractions with an additional 22Gy in 11 fractions to $\mathrm{PTV}_{2}$. Absorbed dose for IMRT was calculated using Monaco ver. 5.11 (Elekta, Stockholm, Sweden) treatment planning system. The prescribed dose was delivered to the patient using 6MV photon beams of the Siemens Oncor Expression (Siemens Healthineers, Erlangen, Germany) linear accelerator. An arrangement of nine coplanar beams at gantry angles $0^{\circ}, 40^{\circ}, 80^{\circ}, 120^{\circ}$, $160^{\circ}, 200^{\circ}, 240^{\circ}, 280^{\circ}$, and $320^{\circ}$ was used. Sequencing parameters were set so that the minimum segment area was $\geq 4 \mathrm{~cm}^{2}$, minimum segment width was $\geq 1 \mathrm{~cm}$, the minimal number of monitor units per segment was 2, and the maximum number of segments per treatment fraction was 100. Delivery mode for the IMRT was step-and-shoot.

For the purpose of this research, dose distributions using the FiF technique were calculated retrospectively, using XiO ver. 5.10 (Elekta, Stockholm, Sweden) treatment planning system. Photon beams of higher nominal potential (18MV) of the same linear accelerator were used for treatment delivery. Beams set at $0^{\circ}, 90^{\circ}, 150^{\circ}, 180^{\circ}$, $200^{\circ}$, and $270^{\circ}$ were used to achieve the dose distribution conformality. Field-in-field technique was used at existing angles to improve conformality, dose homogeneity, eliminate dose hot spots, and achieve better organs-at-risk sparing.

For both planning techniques, dose-volume constraints for target volume coverage were set. They required $\mathrm{V} 95 \%$ of $\mathrm{PTV}_{1}$ and $\mathrm{PTV}_{2}$ to be covered by $98 \%$ of the prescribed dose and V100\% of the same structures to be covered by $85 \%$ of the prescribed dose. In addition, no more than $2 \%$ of the PTV volume was to receive more than $71.4 \mathrm{~Gy}$. The dose constraint for the GTV and CTV was that $100 \%$ of the volume was covered by $98 \%$ of the prescribed dose (68Gy) (10).

For both planning techniques, dose constraints for organs-at-risk followed the dose guidelines designed by the QUANTEC and RTOG $(9,11,12)$. For postoperative radiation treatment of prostate cancer, stricter criteria were used in our clinic. The rectum criteria require that no more than $60 \%, 50 \%$, and $40 \%$ of the rectum volume receives absorbed dose larger than 40Gy, 50Gy, and $60 \mathrm{~Gy}$, respectively. The bladder criteria require that no more than $50 \%, 25 \%$, and $20 \%$ of the bladder volume receive absorbed doses larger than $50 \mathrm{~Gy}, 60 \mathrm{~Gy}, 65 \mathrm{~Gy}$, respectively. It was required for femoral heads that no more than $10 \%$ of the volume receives more than $50 \mathrm{~Gy}$.

The cumulative dose-volume histograms (DVHs) were used for the evaluation and comparison of planning techniques. DVHs were inspected for the following parameters: target volume coverage with $100 \%$ of prescribed dose for GTV, CTV, PTV ${ }_{1}$, and $\mathrm{PTV}_{2}$, target volume coverage with $95 \%$ prescribed dose for $\mathrm{PTV}_{1}$ and $\mathrm{PTV}_{2}$. For organs-at-risk sparing, dose-volume data were reviewed for $\left(\mathrm{V}_{40 G \mathrm{G}^{\prime}}, \mathrm{V}_{50 \mathrm{~Gy}}\right.$ and $\left.\mathrm{V}_{60 \mathrm{~Gy}}\right)$, bladder $\left(\mathrm{V}_{50 \mathrm{~Gy}}\right.$ $\mathrm{V}_{60 \mathrm{~Gy}}$ and $\left.\mathrm{V}_{65 \mathrm{~Gy}}\right)$ and femoral heads $\left(\mathrm{V}_{50 \mathrm{~Gy}}\right)$.

\section{Statistical analysis}

TIBCO Statistica ver. 13.5. software package was used to perform the statistical analysis. The differences between the two techniques in dose to the respective percentage volume were calculated as:

$$
\Delta=\frac{D_{I M R T}-D_{F i F}}{D_{P R}} 100 \%
$$

where $D_{I M R T}$ and $D_{F i F}$ are the doses to the volumeof interest in IMRT and FiF, respectively, and $D_{P R}$ is the prescribed dose. The differences between techniques for volumes coverage with specific doses were calculated as:

$$
\Delta=\% V_{I M R T}-\% V_{F i F}
$$

where $\% V_{I M R T}$ and $\% V_{F i F}$ are the volume coverage for the same absorbed dose in IMRT and FiF techniques, respectively.

The p-value of $<0.05$ was set as the level of significance. Along with Student's t-test, KruskalWallis test was used as a non-parametric test and one-way analysis of variance (ANOVA) as a parametric test.

\section{RESULTS}

Analysis of parameters related to target volumes (GTV, CTV, PTV $\left.{ }_{1}, \mathrm{PTV}_{2}\right)$ has shown that absorbed dose coverage using IMRT was higher for all analyzed parameters. However, most of them did not show any statistically significant 
Table 1.

Mean target volume coverage with corresponding standard deviation (GTV, CTV, PTV1, and PTV2) for IMRT and FiF, accompanied by p-values.

\begin{tabular}{|l|l|l|l|l|}
\hline \multicolumn{2}{|c|}{} & FiF & IMRT & p-value \\
\hline GTV & $\mathrm{V}_{100 \%}(\%)$ & $98,8 \pm 1,3$ & $99,9 \pm 0,2$ & 0,056162 \\
\hline CTV & $\mathrm{V}_{100 \%}(\%)$ & $99,4 \pm 0,9$ & $99,4 \pm 0,8$ & 0,055424 \\
\hline \multirow{2}{*}{ PTV } & $\mathrm{V}_{100 \%}(\%)$ & $93,3 \pm 2,0$ & $95,8 \pm 2,4$ & 0,042944 \\
\cline { 2 - 5 } & $\mathrm{V}_{95 \%}(\%)$ & $99,3 \pm 0,6$ & $99,9 \pm 0,1$ & 0,060417 \\
\hline \multirow{2}{*}{ PTV $_{2}$} & $\mathrm{~V}_{100 \%}(\%)$ & $91,6 \pm 3,8$ & $97,9 \pm 1,4$ & 0,000534 \\
\cline { 2 - 5 } & $\mathrm{V}_{95 \%}(\%)$ & $99,9 \pm 0,2$ & $99,7 \pm 0,4$ & 0,242502 \\
\hline
\end{tabular}

difference $\left(\mathrm{V}_{100 \%}(\mathrm{GTV}), \mathrm{V}_{100 \%}(\mathrm{CTV}), \mathrm{V}_{95 \%}\left(\mathrm{PTV}_{2}\right)\right.$, $\left.\mathrm{V}_{95 \%}\left(\mathrm{PTV}_{1}\right)\right)$. The results are presented in Table 1.

Statistically, a significant difference was found for V100\% target volume coverage for PTV and $\mathrm{PTV}_{2}$, with $\mathrm{p}=0,042944$ and $\mathrm{p}=0,000534$, respectively, with higher planning target volume coverage achieved using IMRT.

A comparison of dose distributions regarding two planning techniques was performed for organs-at-risk that were found to be clinically relevant for the treatment outcome. The results for rectum, bladder, and femoral heads are shown in Table 2. A statistically significant difference $(p=0,045966)$ was found for rectum, for criterion requiring that no more than $40 \%$ of the rectum volume receive absorbed dose larger than 60Gy. For dose-volume constraints related to the bladder, no statistically significant difference was found. Observing the DVHs, a difference was noticed for lower doses, and the additional analysis was made for the percentage of femoral heads volume receiving a dose of $30 \mathrm{~Gy}\left(\mathrm{~V}_{30 \mathrm{~Gy}}\right)$. A statistically significant difference was found $(p=0,000385)$ in favor of IMRT.

\section{Table 2.}

Mean value of the organs-at-risk dose-volume coverage for the following dose-volume constraints: rectum $\left(V_{40 \mathrm{G}}, V_{50 \mathrm{G}}\right.$ and $\left.V_{60 G y}\right)$, bladder $\left(V_{50 G y^{\prime}} V_{60 G y}\right.$ and $\left.V_{65 G y}\right)$ and femoral heads $\left(V_{30 \mathrm{G} y}, V_{50 \mathrm{G} y}\right)$, accompanied with p-values.

\begin{tabular}{|c|c|c|c|c|}
\hline & FiF & IMRT & $p$-value \\
\hline \multirow[t]{3}{*}{ Rectum } & $\mathrm{V}_{40 G \mathrm{G}}(\%)$ & $66,64 \pm 12,9$ & $53,43 \pm 11,14$ & 0,045966 \\
\hline & $\mathrm{V}_{50 \mathrm{GG}}(\%)$ & $45,89 \pm 14,68$ & $38,85 \pm 11,65$ & 0,306166 \\
\hline & $V_{60 G y}(\%)$ & $28,23 \pm 8,62$ & $27,486 \pm 8,93$ & 0,867383 \\
\hline \multirow[t]{3}{*}{ Bladder } & $\mathrm{V}_{50 \mathrm{~Gy}}(\%)$ & $49,33 \pm 18,36$ & $38,45 \pm 10,33$ & 0,166288 \\
\hline & $\mathrm{V}_{600 \mathrm{G}}(\%)$ & $35,41 \pm 14,61$ & $29,91 \pm 9,76$ & 0,390927 \\
\hline & $V_{656 \mathrm{y}}(\%)$ & $28,13 \pm 12,92$ & $25,72 \pm 9,25$ & 0,590504 \\
\hline \multirow{2}{*}{$\begin{array}{l}\text { Femoral } \\
\text { heads }\end{array}$} & $\mathrm{V}_{30 \mathrm{~Gy}}(\%)$ & $75,62 \pm 29,21$ & $25,81 \pm 8,38$ & 0,000385 \\
\hline & $\mathrm{V}_{506 \mathrm{y}}(\%)$ & $1,13 \% \pm 1,64$ & $1,23 \pm 1,54$ & 0,924183 \\
\hline
\end{tabular}
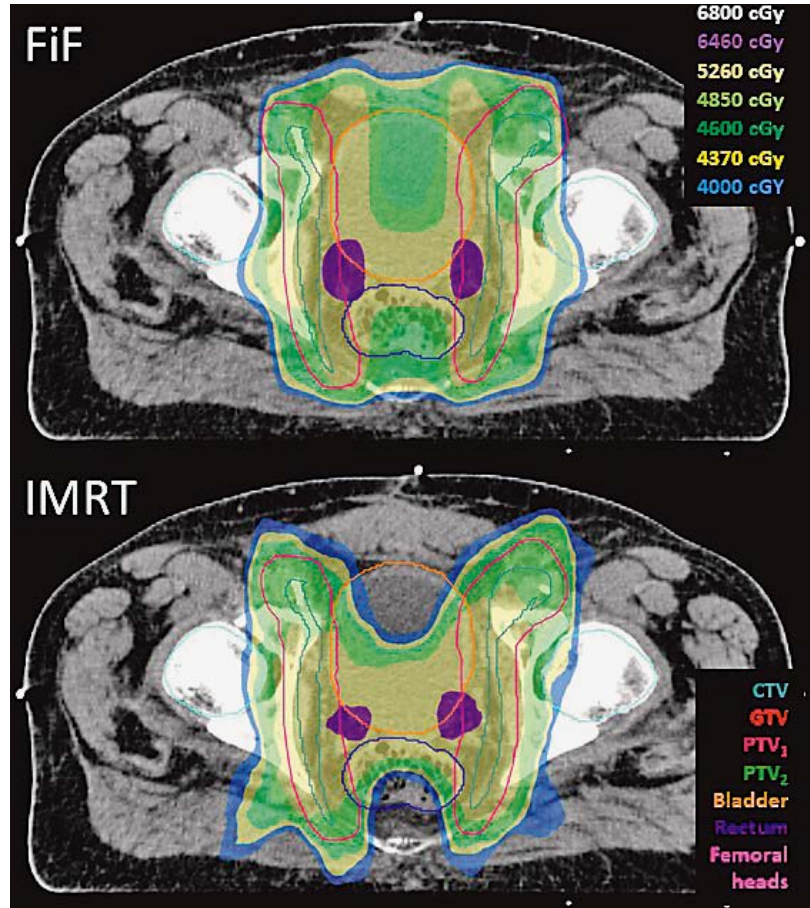

Figure 1. Dose distribution showing target volume coverage and the organs-at-risk sparing for FiF (top) and IMRT (bottom) on the same transversal slice of a lymph node region for one study patient.

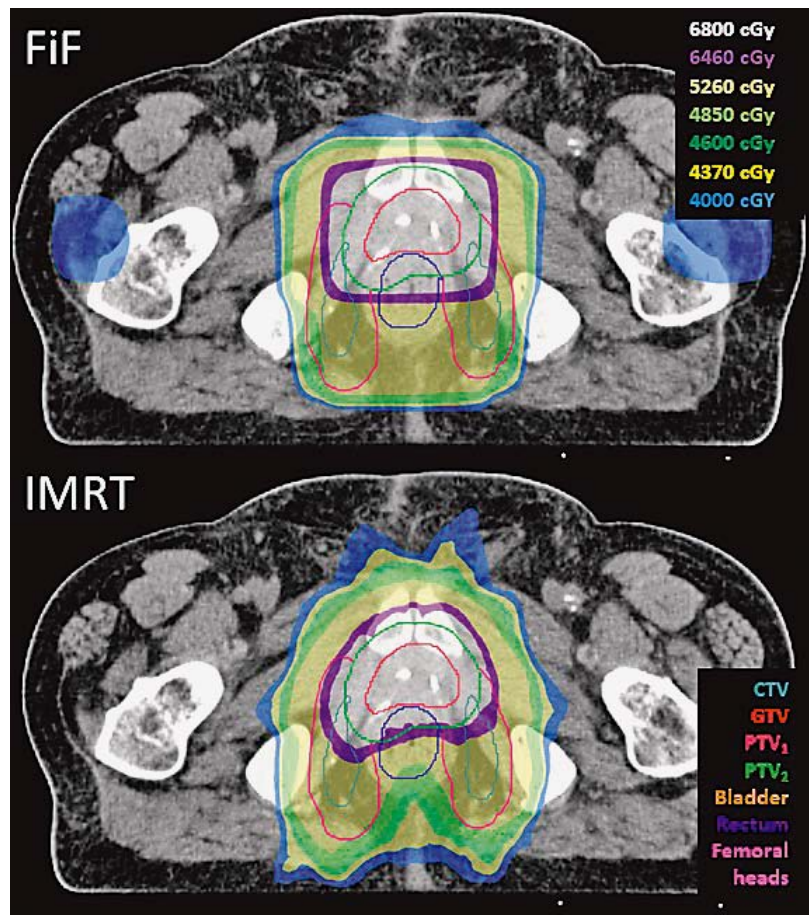

Figure 2.Dose distribution showing target volume coverage and the organs-at-risk sparing for FiF (top) and IMRT (bottom) on a transversal slice of the prostate bed region for one study patient. 


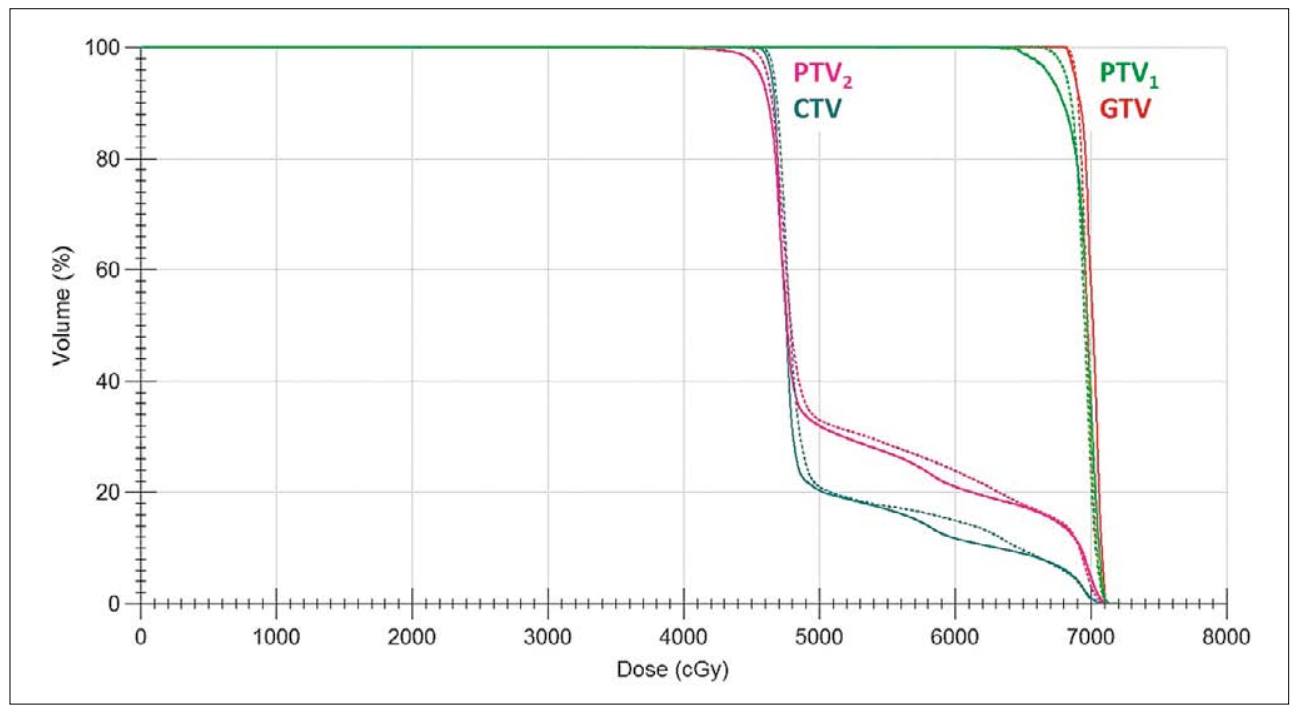

Figure 3.Dose-volume histogram displaying coverage of target volumes (GTV, CTV, PTV ${ }_{1}$ and PTV ) for FiF (full line) and IMRT (dotted line).

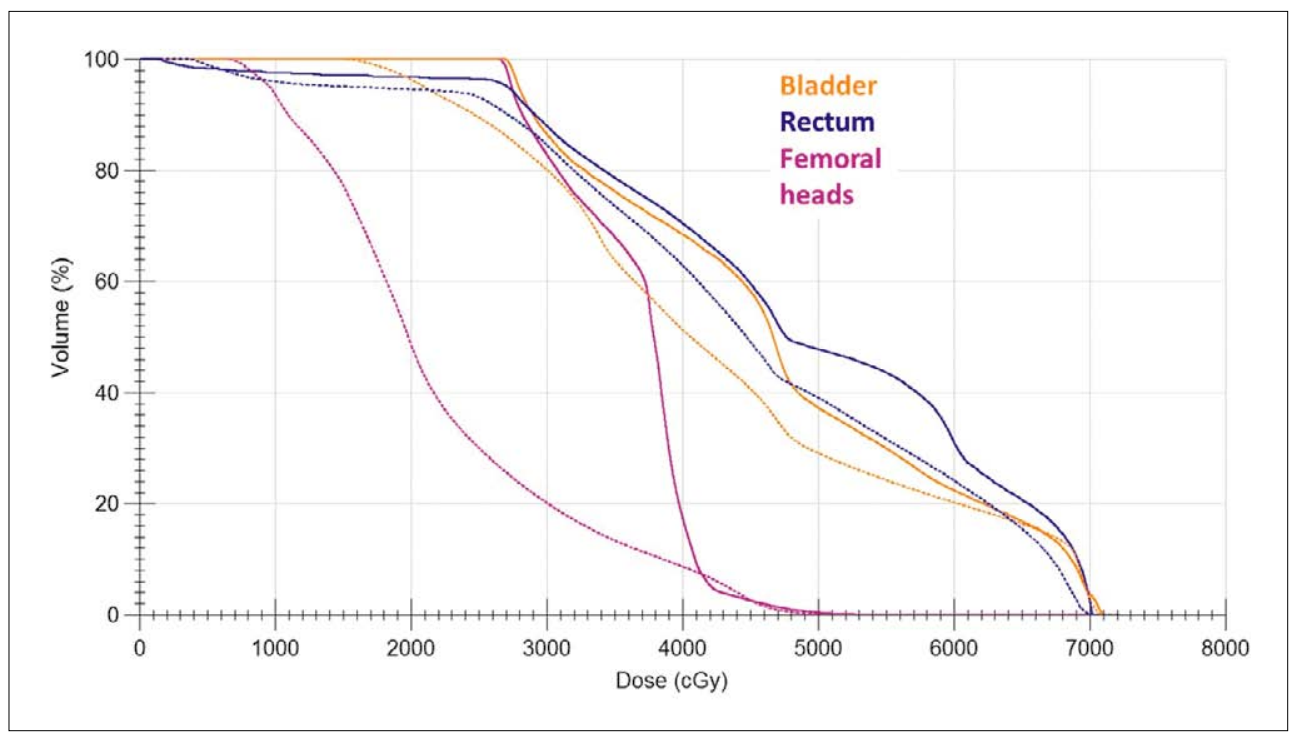

Figure 4. Dose-volume histogram displaying absorbed dose received by the organs-at-risk (bladder, rectum, and femoral heads) for FiF (full line) and IMRT (dotted line).

Absorbed dose distribution on the same transversal slice of one study patient for both planning techniques is shown in Figures 1 and 2. The lymph node region is shown in Figure 1, while the prostate bed region is shown in Figure 2.

Dose-volume histogram (DVH) with cumulative doses to target volumes and organs-at-risk (rectum, bladder, and femoral heads) for one study patient is shown in Figures 3 and 4 .

\section{DISCUSSION}

The treatment of prostate cancer has evolved so that a substantial proportion of patients has a higher life expectancy after radiotherapy. Late toxicities from radiotherapy can significantly impact the patient's quality of life (13). According to the published studies, IMRT enables higher dose delivery to the target volumes with better sparing 
of normal tissues compared to 3-DCRT $(7,14)$. Results of this research confirm this statement considering some of the inspected parameters.

Target coverage of GTV with $100 \%$ of the prescribed dose using the FiF technique was only slightly lower than GTV coverage using IMRT, and no statistically significant difference between the techniques was found in that regard. No statistically significant difference was found for $100 \%$ of the prescribed dose volume coverage for CTV either, where the target coverage with the absorbed dose was the same for both techniques. When analyzing volume coverage with $95 \%$ of the prescribed dose of $\mathrm{PTV}_{1}$ and $\mathrm{PTV}_{2^{\prime}}$ the differences between the two planning techniques were minor and statistically insignificant. However, a statistically significant difference was found for coverage with $100 \%$ of the prescribed dose for $\mathrm{PTV}_{1}$ and $\mathrm{PTV}_{2}$ in favor of IMRT, with differences between target volume coverage as high as $5.03 \%$ and $11.27 \%$, for $\mathrm{PTV}_{1}$ and $\mathrm{PTV}_{2}$, respectively.

Target volume coverage with prescribed dose is significant in treatment planning; however, it must be achieved in compromise with dose-volume coverage of organs-at-risk. Better organs-atrisk sparing reduces the incidence of acute and late toxicities in these structures (8). Comparing data from Tables 1 and 2 for all analyzed parameters, it was found that the use of IMRT could provide better organs-at-risk sparing than the FiF technique. Differences in bladder sparing were shown to be statistically insignificant for all inspected dose-volume constraints. Dose-volume sparing was shown to be better with IMRT when analyzing parameters regarding rectum sparing. No statistically significant difference was found regarding the volume of the rectum receiving 50Gy and 60Gy $\left(\mathrm{V}_{50 \mathrm{~Gy}}\right.$ and $\left.\mathrm{V}_{60 \mathrm{~Gy}}\right)$, but a statistically significant difference was found for the volume of the rectum receiving $40 \mathrm{~Gy}\left(\mathrm{~V}_{40 \mathrm{~Gy}}\right)$ in favor of IMRT. Concerning femoral heads, no statistically significant difference was found between FiF and IMRT regarding the volume receiving 50Gy $\left(\mathrm{V}_{50 \mathrm{~Gy}}\right)$. A statistically significant difference $(p=0,00385)$ in favor of IMRT was found for volumes of femoral heads receiving lower doses (30Gy, $\mathrm{V}_{30 \mathrm{~Gy}}$ ). Zelefsky et al. have reported that no statistically significant difference was found between planning techniques when it comes to the incidence of longterm hip-related toxicity (15).

\section{CONCLUSION}

The statistically significant difference in target volume coverage by $100 \%$ of the absorbed dose was found for $\mathrm{PTV}_{1}$ and $\mathrm{PTV}_{2}$; better coverage being achieved with IMRT.

No statistically significant difference in favor of IMRT was found for organs-at-risk sparing, except in the case for a volume of the rectum which receives $40 \mathrm{~Gy}\left(\mathrm{~V}_{40 \mathrm{~Gy}}\right)$ and in the case for a volume of femoral heads which receives 30Gy $\left(\mathrm{V}_{30 \mathrm{~Gy}}\right)$.

Expectedly, better results were achieved for IMRT (16). However, differences between the FiF technique and the IMRT for prostate cancer treatment were shown to be statistically insignificant for most analyzed parameters, which point to the fact that well-planned and executed radiation oncology treatment of prostate cancer by using the 3-DCRT FiF technique can also be considered as a technique of choice.

\section{REFERENCES}

1. Barton MB, Jacob S, Shafiq J, et al. Estimating the demand for radiotherapy from the evidence: A review of changes from 2003 to 2012. Radiother Oncol. 2014;112:140-144.

2. Ferlay J, Ervik M, Lam F, et al.(2018). Global Cancer Observatory: Cancer Today. Lyon, France: International Agency for Research on Cancer. Available from: https://gco.iarc.fr/today/data/factsheets/ populations/191-croatia-fact-sheets.pdf, accessed [14October2020].

3. National Comprehensive Cancer Network (NCCN). NCCN clinical practice guidelines in oncology (NCCN Guideline): Prostate cancer (version 4.2019). Available from: https://www.nccn.org/patients/guidelines/content/PDF/prostate-patient.pdf, accessed [14 October 2020].

4. Ohri N, Shen X, Den RB, et al. Salvage radiotherapy for prostate cancer. Finding a way forward using radiobiological modelling. Cancer BiolTher. 2012;13(14):1449-1453.

5. Boorjian SA, Karnes JR, Crispen PL, et al. Radiation therapy after radical prostatectomy: impact on metastasis and survival. J Urol. 2009;182(6):2708-14.

6. The Royal College of Radiologists (RCR). Radiotherapy dose fractionation, third edition. (2019). Available from: https://www.rcr.ac.uk/publication/radiotherapy-dose-fractionation-third-edition, accessed [14October2020].

7. Fischer-Valuck BW, Rao YJ, Michalski JM. Intensitymodulated radiotherapy for prostate cancer. Transl Androl Urol 2018;7(3):297-307.

8. Zelefsky MJ, Levin EJ, Hunt M, et al. Incidence of late rectal and urinary toxicities after three-dimensional 
conformal radiotherapy and intensity-modulated radiotherapy for localized prostate cancer. Int J Radiat Oncol Biol Phys. 2008;70(4):1124-1129.

9. Michalski J, Purdy J, Bruner DW, et al. A phase III randomized of high dose 3D-CRT/IMRT versus standard dose 3D-CRT/IMRT in patients treated for localized prostate cancer [Electronic version]. RTOG-0126. Philadelphia (PA): Radiation Therapy Oncology Group; 2004. Available at: www.rtog.org/members/numericactive.html, accessed[5 October 2007].

10. International Commission on Radiation Units and Measurement (ICRU). ICRU Report 83: prescribing, recording, and reporting photon-beam intensity-modulated radiation therapy (IMRT). J ICRU 2010;10(1):NP.

11. Michalski JM, Gay H, Jackson A, et al. Radiation dosevolume effects in radiation-induced rectal injury. Int J Radiat Oncol Biol Phys. 2010;76(3)(suppl s123-129).
12. Viswanathan AN, Yorke ED, Lawrence BM, et al. Radiation dose-volume effects of the urinary bladder. Int J Radiat Oncol Biol Phys. 2010;76(3)(suppl s116-122).

13. Emami, B. Tolerance of normal tissue to therapeutic radiation. Rep Radiother Oncol. 2013;1:1.

14. Staffurth J. A review of the clinical evidence for intensity-modulated radiotherapy. Clin Oncol (R Coll Radiol) 2010;22:643-657.

15. Zelefsky MJ, Kollmeier MA, Gorshein E, et al. Hip-related after prostate radiotherapy: Treatment related or coincidental? Radiother Oncol. 2016;121:109-112.

16. Bruner DW, Hunt D, Michalski JM, et al. Preliminary patient-reported outcomes analysis of 3-dimensional radiation therapy versus intensity-modulated radiation therapy on the high-dose arm of the Radiation Therapy Oncology Group (RTOG) 0126 prostate cancer trial. Cancer 2015;121:2422-2430.

Sažetak

\title{
UTJECAJ IZBORA TEHNIKE PLANIRANJA FiF/IMRT KOD RADIOTERAPIJE OPERIRANE PROSTATE
}

\author{
N. Obajdin, Đ. Smilović Radojčić, D. Zahirović, M. Švabić Kolacio, D. Rajlić, I. Belac Lovasić i S. Jurković
}

Uvod: U posljedna dva desetljeća, u liječenju raka prostate radioterapijom postignut je veliki napredak. U KBC-u Rijeka, od 2016., jakosno modulirana radioterapija (IMRT) postaje tehnika izbora kod radioterapije operiranog raka prostate. Do tada je tehnika izbora bila napredna 3D konformalna radioterapija (3DCRT) korištenjem tehnike „polja u polju” (FiF). Istraživanje je provedeno s ciljem ispitivanja utjecaja izbora tehnike planiranja (FiF ili IMRT) na doznu pokrivenost ciljnih volumena i poštedu organa rizika.

Metode i materijali: Usporedba raspodjela doze izračunate koristeći FiF i IMRT retrospektivno je učinjena kod deset bolesnika kojima je indicirana postoperativna radioterapija. Svim je bolesnicima predana propisana doza IMRT tehnikom, a za potrebe ovog istraživanja izračunate su i raspodjele doze FiF tehnikom. Da bi se utvrdilo utječe li tehnika planiranja na raspodjelu doze, analizirani su parametri važni za ciljne volumene $\left(\mathrm{GTV}, \mathrm{CTV}, \mathrm{PTV}_{1}, \mathrm{PTV}_{2}\right)$, a kod analize poštede organa rizika (rektum, mokraćni mjehur i glavice femura) korištena su dozno-volumna ograničenja.

Rezultati i diskusija: Analizom parametara vezanih za ciljne volumene utvrđeno je da kod većine (V100\%(GTV), V100\%(CTV), V95\% $\left(\mathrm{PTV}_{2}\right)$, V95\%(PTV $\left.{ }_{1}\right)$ nema statistički značajne razlike. Kod obje tehnike postignuta su dozna ograničenja propisana međunarodnim smjernicama.

Statistički značajna razlika utvrđena je kod V100\% $\left(\mathrm{PTV}_{2}\right), \mathrm{p}=0,000534$ i V100\% $\left(\mathrm{PTV}_{1}\right), \mathrm{p}=0,042944$ u prilog korištenja IMRT tehnike. Utvrđena je statistički značajna razlika $(p=0,045966)$ za volumen rektuma koji prima $40 \mathrm{~Gy}$, kao i za volumen glavica femura koji prime apsorbiranu dozu 30Gy. U oba slučaja pošteda organa rizika bolja je korištenjem IMRT tehnike. Za promatrana dozno-volumna ograničenja vezana uz mokraćni mjehur nije utvrđena statistički značajna razlika.

Zaključak: Rezultati istraživanja pokazuju statistički značajnu razlikukod usporedbe volumena kojemu je predana pro-

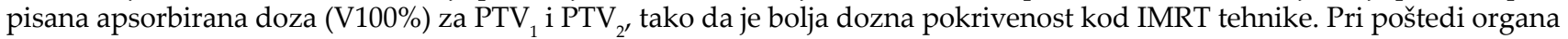
rizika statistički značajna razlika u korist IMRT-a utvrđena je kod analize volumena rektuma kojem je predana apsorbirana doza od 40Gy i volumena glavica femura kojima je predana apsorbirana doza od 30Gy. Prema očekivanju, IMRT daje bolje rezultate. Međutim, razlike u analiziranim parametrima između dvije tehnike planiranja (FiF ili IMRT) kod većine analiziranih parametara nisu statistički značajne što upućuje da kvalitetno planirana radioterapija FiF tehnikom može također biti tehnika izbora.

KLJUČNE RIJEČI: jakosno modulirana radioterapija IMRT, tehnika „polja u polju”, radioterapija operiranog raka prostate, dozimetrija 